\title{
DESAIN PERANGKAT ANALISIS MUTU PELAYANAN RUMAH SAKIT
}

\author{
Andy Triyanto Pujo R \\ Fakultas Teknik, Teknik Informatika \\ Universitas Muhammadiyah Ponorogo \\ Email: andytriyanto244@gmail.com
}

\begin{abstract}
ABSTRAK
Keberadaan sebuah rumah sakit sangat vital dalam memberikan jasa pelayanan medis kepada masyarakat luas. Oleh karena itu pelayanan yang dilakukan oleh pihak rumah sakit kepada pasiennya harus dijaga dengan baik agar dapat memuaskan pasien. Demikian juga masyarakat harus mengetahui tentang kualitas mutu pelayanan sebuah rumah sakit. Dalam hal ini pemerintah juga memberikan standart penilaian mutu pelayanan rumah sakit kepada instansi-instansi rumah sakit agar dapat menjaga kepuasan pasien.Perangkat analisis mutu pelayanan rumah sakit ini dibangun untuk membantu pihak manajemen/pimpinan rumah sakit dalam menghitung mutu pelayanan yang mempunyai standart nasional. Masyarakat atau juga calon pasien juga diuntungkan karena mendapatkan informasi kualitas mutu layanan sebuah rumah sakit.Pengembangan perangkat analisis ini diharapkan dapat menjadi sebuah fitur tambahan yang memudahkan pihak manajemen atau pimpinan rumah sakit dalam menghitung dan menentukan mutu pelayanan rumah sakit. Metode yang digunakan dalam penelitian ini menggunakan metode pengumpulan data dan pengembangan sistem. Hasil penelitian berdasarkan wawancara yang dilakukan menunjukkan bahwa sistem yang dibuat sudah sesuai dengan aturan di rumah sakit dan perhitungannya lebih komplit dari yang sudah ada.
\end{abstract}

Kata kunci: perangkat analisis, mutu pelayanan rumah sakit, pelayanan medis.

\begin{abstract}
The existence of a hospital is vital in providing medical services to the public. Therefore services carried out by the hospital to the patient should be maintained properly in order to satisfy the patient. Likewise, people should know about the quality of service quality of a hospital. In this case the government also provides a quality assessment standard of hospital services to agencies in order to keep the hospital patient satisfaction. The device analyzes the quality of service of this hospital was built to help the management / leadership of the hospital in calculating the quality of service that has a national standard. Community or also prospective patients also benefit because the information quality of the service quality of a hospital. The development of an analytical tool is expected to be an additional feature that facilitates the management or leadership of the hospital in calculating and determining the quality of hospital services. The method used in this study using data collection and system development. The results based on interviews carried out shows that the system is made in conformity with the rules of the hospital and the calculation is more complete than the existing ones.
\end{abstract}

Keywords: analysis tools, the quality of hospital services, medical services.

\section{PENDAHULUAN}

Rumah Sakit adalah sebuah organisasi yang sangat kompleks. Manajemennya hampir sama dengan manjemen sebuah hotel. Mutu pelayanan rumah sakit adalah pelayanan kesehatan yang menunjuk pada tingkat kesempurnaan penampilan pelayanan kesehatan yang diselenggarakan yang disatu pihak dapat memuaskan para pemakai jasa pelayanan dan di pihak lain tata cara penyelenggaraannya sesuai dengan kode etik profesi serta standart yang telah ditetapkan [1]

Pelayanan kesehatan di rumah sakit saat ini tidak saja bersifat penyembuhan tetapi juga bersifat pemulihan. Keduanya dilaksanakan secara terpadu melalui upaya promosi kesehatan dan pencegahan. Dengan demikian, sasaran pelayanan rumah sakit bukan hanya pasien tetapi juga perkembangan untuk keluarga pasien dan masyarakat umum [2]. Pelayanan di rumah sakit sangatlah menjadi prioritas utama dalam kegiatan di rumah sakit. Salah satu pelayananya adalah pengolahan jumlah data pasien,. Jumlah data pasien adalah data seluruh pasien yang di rawat di rumah sakit tersebut. Data tersebut sangat di butuhkan oleh rumah sakit, sehingga rumah sakit dapat memantau kondisi pasien dan informasi tentang pasien. Bagi pasien data tersebut dapat menjadi acuan tentang kulitas rumah sakit tersebut. 
Pengolahan jumlah data pasien di rumah sakit biasanya masih menggunakan cara manual. Secara umum pengolahan jumlah data pasien sudah berjalan dengan lancar sesuai dengan perhitunganya, namun secara manual mempunyai kelemahan yaitu memerlukan waktu yang lama dan Ancaman pada akurasi dan ketelitian data, dikarenakan kemampuan manusia yang terbatas. Kelemahan tersebut akan mempengaruhi mutu pelayanan rumah sakit.

Dengan latar belakang diatas maka akan dibuat sistem informasi penilaian mutu pelayanan rumah sakit berdasarkan standar nasional. Sistem ini akan memberikan hasil nilai pelayanan rumah sakit berdasarkan jumlah pasien yang di rawat oleh rumah sakit tersebut.

\section{METODOLOGI PENELITIAN}

Metode yang digunakan untuk penelitian ini adalah metode pengumpulan data dan pengembangan sistem. Metode pengumpulan data adalah metode yang digunakan untuk mengumpulkan data-data yang dibutuhkan dalam penyelesaian penelitian. Metode tersebut meliputi :

a. Observasi

Metode ini dilakukan untuk mendapatkan data atau informasi yang berkaitan dengan sistem informasi penilaian mutu pelayanan rumah sakit berdasarkan standar nasional .

b. Kepustakaan

Metode ini mempelajari buku - buku yang berhubungan sistem informasi penilaian mutu pelayanan rumah sakit berdasarkan standar nasional dan permasalahan yang berhubungan dengan penyusunan penelitian ini.

Metode pengembangan sistem adalah serangkaian langkah-langkah yang harus dilakukan dalam membangun sistem atau aplikasi perangkat lunak :

a. Analisis Sistem

Sistem dianalisis dengan mengidentifikasi masalah, model keputusan yang digunakan, analisis kebutuhan sistem berupa input, output, proses, use case, dan interface sebagai batasan dalam pembuatan sistem.

b. Desain

Tahap ini merupakan tahap perancangan sistem dari alur sistem yang akan dibuat mengunakan unified modeling language (UML) dan desain basis data yang di jelaskan dalam bentuk table serta perancangan antar muka yang ditunjukan lewat gambar.

c. Implementasi

Tahap ini adalah tahap penerjemahan dari pengetahuan yang telah didapatkan sebelumnya ke dalam bahasa pemrograman PHP

d. Pengujian

Tahap ini adalah tahap akhir berupa pengujian sistem yang telah dibangun. Sistem akan diuji hingga mendapatkan hasil akhir yang maksimal.

\section{HASIL PEMBAHASAN}

Menurut Azrul Azwarmutu pelayananRumah Sakit adalah pelayanan kesehatan yang menunjuk pada tingkat kesempurnaan penampilan pelayanan kesehatan yang diselenggarakan yang disatu pihak dapat memuaskan para pemakai jasa pelayanan dan dipihak lain tata cara penyelenggaraannya sesuai dengan kode etik profesi serta standar yang telah ditetapkan.

\subsection{Rumus untuk Menghitung Pelayanan Rumah Sakit}

\subsubsection{Rumus Mutu Pelayanan}

Rumus menghitungmutupelayanan Rumah Sakit[3]:

a. BedOccupancyRate(BOR)

Persentase pemakaiantempattidurpada satusatuanwaktutertentu.Indikatorini memberikan gambaran tentang tinggi rendahnya tingkat pemanfaatan tempat tidurRumah Sakit.

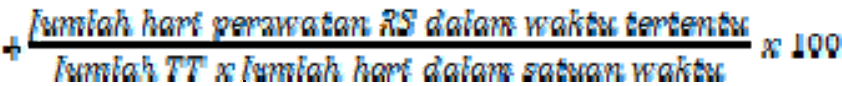


b. AverageLengthofStay (ALOS)

Rata-rata lamanya perawatan seorang pasien. Indikator ini disamping merupakan gambaran tingkat efisiensi manajemen sebuah Rumah Sakit, indikator ini juga dapat dipakai untuk mengukur mutu pelayanan apabila diagnosis penyakit tertentu dapat dijadikan tracernya (yang perlu pengamatan lebih lanjut).

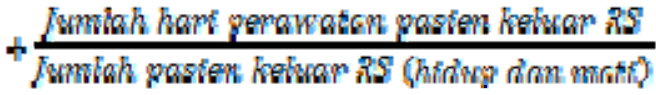

c. BedTurnOver (BTO)

Frekuensi pemakaian tempat tidur dalam satu satuan waktu (biasanya pertahun) tempat tidur Rumah Sakit. Indikator ini akan memberikan gambaran tingkat pemakaian tempat tidur Rumah Sakit.

Wmiah pasten ketwan $R S$ (hidw? + mate)

Jumbh tervation thap

d. TOI (TurnOver Interval)

Rata-rata hari tempat tidur tidak ditempati dari saat ke saat sampai terisi berikutnya. Indikator ini juga menberikan gambaran tingkat efisiensi penggunaan tempat tidur.

\section{(ywhah TT shaw) - haw perawatax RS

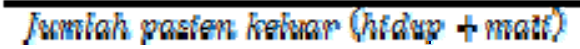

e. NDR (Net Death Rate)

Angka kematian diatas 48 jam setelah dirawat untuk tiap-tiap 100 penderita keluar Rumah Sakit.

Kombah parten mote diatas 48 jom dirawat

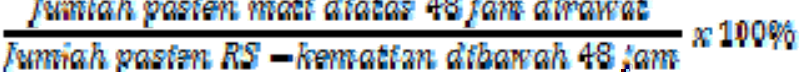

f. $G D R$ (Gross Death Rate)

Angka kematian umum penderita keluar dari RS

Wmiah parten mate sohwshnya ditrawat

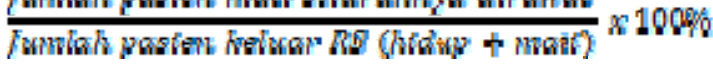

g. NetInfectionRate

Angka infeksi yang didapat dari rumah sakit yang terjadi pada pasien yang dirawat selama 72 jam dan pasien tersebut tidak menunjukkan tanda dan gejala infeksi pada saat masuk rumah sakit.

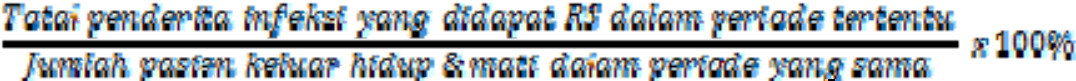

h. Anasthesia DeathRate

Angka kematian anastesi pasien karena overdosis dan reaksi anastesi tersebut.

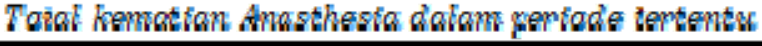

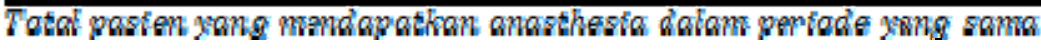

i. PostOperationDeathRate

Angka kematian pasca bedah operasi.

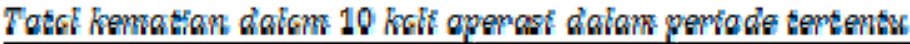
Tatal pasten yang diperast dain periode yang sana $x 100 \%$ 
j. Normal TissueRemoval Rate

Angka jaringan kanker yang diangkat.

Total mamal Tiswe yang dimghat

$$
\text { Tatal Tisse yang diperthea } 4100 \%
$$

k. Maternal DeathRate

Angka kematian ibu melahirkan.

\section{Wmiah parten kebidanan zang maning gal dakan peride tertentw $x 100 \%$

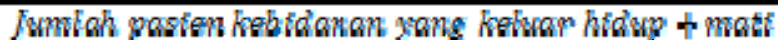

1. Foetal Death Rate

Jumlah Kematian bayi kurangdari 20 minggu.

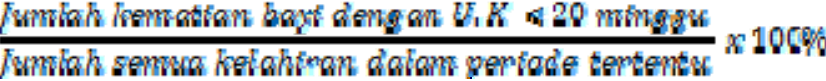

m. ContactRate (5mil)

Angkarata-ratapasienyangkeluardari RS.

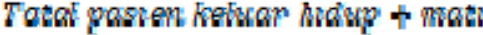

$$
\text { Jwitah popabot } x 120 \%
$$

n. Hospitalization Rate

Angka rata-rata pasien yang dirawat di RS.

\section{$\frac{\text { Tatal haw mawat }}{\text { Fwmiah popwagl }} \times 100 \%$}

o. OutPatientRate

Angka rata-rata kunjungan pasien dalam RS.

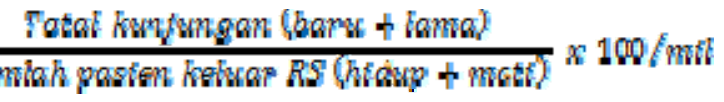

p. Emergency OutRate Patient

Angka rata- rata kunjungan pasien gawat darurat di RS.

\section{Total Wumpuram pasion pawat damprat}

$$
\text { Jwmikh popwiagi } x 100 \%
$$

Variabel diatas digunakan untuk menghitung mutu pelayanan rumah sakit. Variabel-variabel tersebut kemudian dimasukkan kedalam rumus mutu pelayanan rumah sakit untuk memberikan hasil tentang kualitas mutu pelayanan yang berstandart nasional. Hasil perhitungan standar mutu pelayanan rumah sakit harus dibandingkan dengan masing-masing standar mutu nasional.

\subsubsection{Standar Nasional Untuk Mutu Pelayanan Rumah Sakit Di Indonesia}

Standar mutu pelayanan Rumah Sakit [3] :
1) BOR
: $75-85 \%$
2) ALOS
: 7-10 hari
3) $\mathrm{TOI}$
: 1-3 hari
4) $\mathrm{BTO}$
: 5-45 hari
5) $\operatorname{NDR}(48$ jam $)$
$:<2,5 \%$
6) GDR
$:<3 \%$
7) Anasthesia Death Rate
$: 1 / 5000$
8) Post Operation Death Rate
$:<1 \%$ 
9) Post Operative Infection Rate $\quad:<1 \%$

10) Normal Tissue Removal Rate $\quad:<10 \%$

11) Maternal Death Rate $\quad:<0,25 \%$

12) Neonatal Death Rate $\quad:<2 \%$

13) Angka Infeksi Nosokomial : : $1-2 \%$

\subsubsection{Analisa Kebutuhan Antarmuka} berikut:

Analisis kebutuhan antarmuka untuk sistem informasi mutu pelayanan rumah sakit adalah sebagai

1) Front office

a. Halaman utama

Halaman utama digunakan sebagai antar muka pada saat front office dan manajemen mengakses sistem. Berisi info, login front office, login manajemen, dan menu yang berada dalam sistem.

b. Halaman input Data Diri Pasien

Halaman data diri pasien digunakan untuk memasukan data pasien.

c. Halaman manajemen data pasien

Halaman manajemen data pasien digunakan untuk mengubah data pasien.

d. Halaman input data tiap variabel/parameter

Halaman input data tiap variabel/parameter digunakan untuk memasukan data data parameter mutu pelayanan rumah sakit.

e. Halaman input nilai keseluruhan variable

Halaman input nilai keseluruhan variable digunkan untuk mengakumulasikan seluruh jumlah nilai nilai tiap variabel atau parameter.

2) Managemen

a. Halaman utama.

Halaman utama digunakan sebagai antar muka pada saat front office dan managemen mengakses sistem. Berisi info, login front office, login managemen,dan menu yang berada dalam sistem.

b. Halaman hitung

Halaman hitung digunakan untuk memasukan tiap tiap jumlah keseluruhan variabel kedalam rumus mutu pelayanan.

c. Halaman kesimpulan

Dalaman kesimpulan digunakan untuk menyimpulkan hasil perhitungan, berupa saran dan kesimpulan.

\subsection{Relasi Tabel}

Relasi tabel digunakan untuk mempermudah pembuatan program dimana didalamnya terdapat tabeltabel yang saling berhubungan antara table satu dengan tabel lain. Dalam system ini terdapat enam table yang saling berkaitanyaitu, table admin, tindakan, ruangan, kunjungan, pasien, tindakan kunjungan.

Pada data kunjungan melibatkan tiga table yaitu table pasien, table tindakan kunjungan, dan table ruangan. Relasione tomany diperlihatkan pada table kunjungan terhadap table pasien dan table ruangan.Dan tabel tindakan kunjungan one to many ke tabel tindakan dan tabel kunjungan. Relasi table yang digunakan dalam system ini dapat dilihat pada gambar1. 


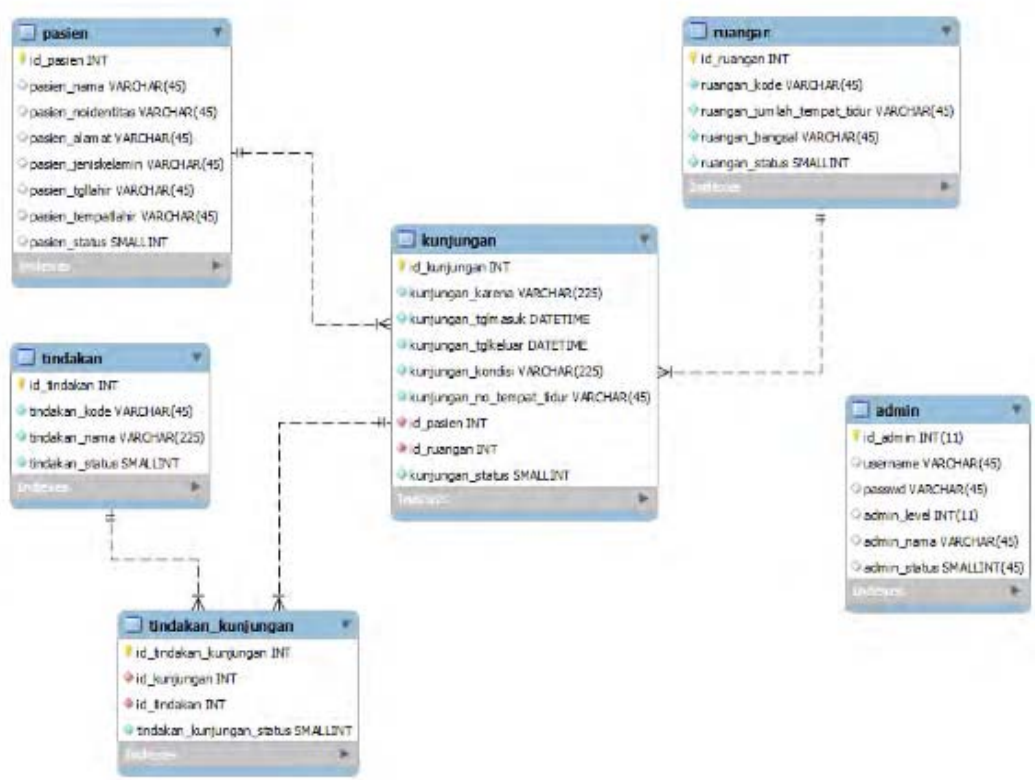

Gambar 1. Relasi Tabel

\subsection{Implementasi Sistem}

\subsubsection{Halaman Mutu Pelayanan}

Halaman mutu pelayanan adalah halaman yang digunakanan untuk menghitung hasil keseluruhan tindakan pasien. Halaman ini bersangkutan dengan halaman kunjungan, karena data keseluruhan pasien akan direkap di halaman ini, dengan menggunakan dua form tanggal awal dan tanggal akhir sebagai date rangenya.Tanggal awal untuk menginputkan tanggal periode awal dan tanggal akhir untuk menginputkan tanggal periode akhir. Setelah diinputkan akan tampil parameter dan total hasilnya. Halaman dapat dilihat pada gambar 2 dibawah.

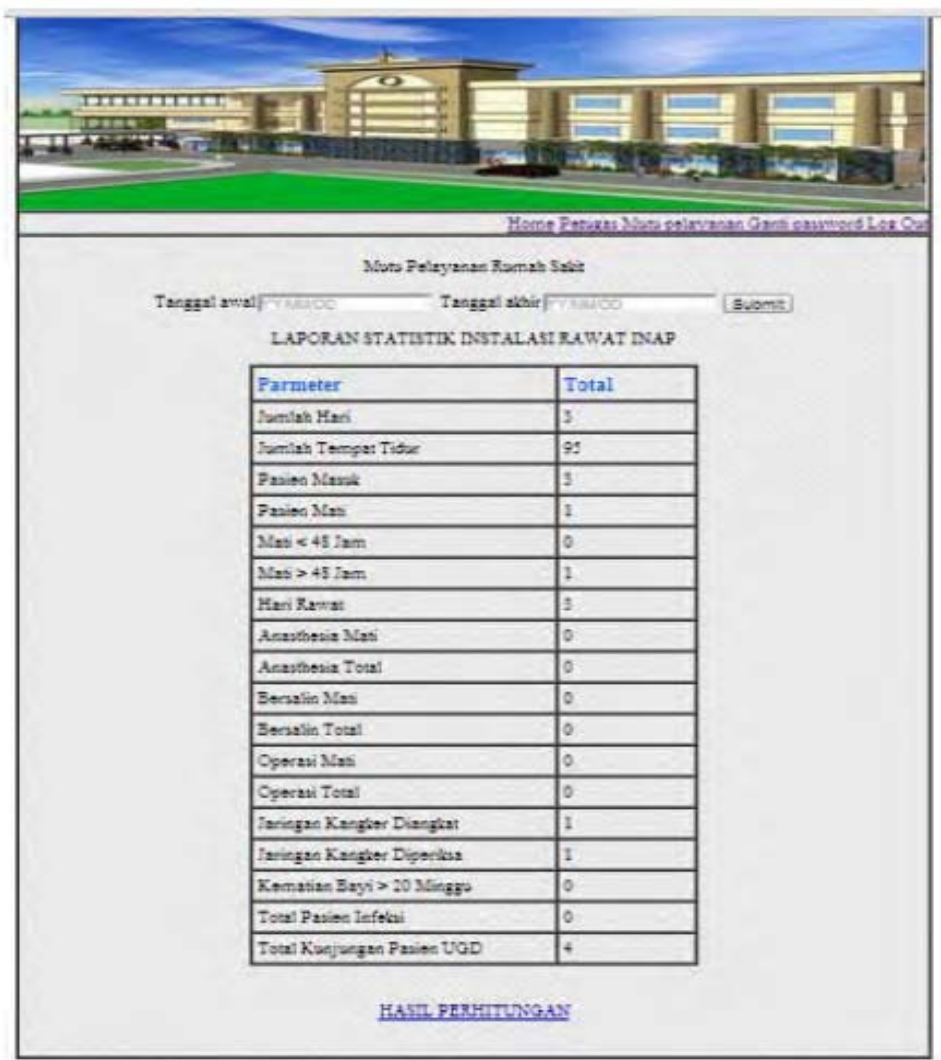

Gambar 2. Halaman Mutu Pelayanan 


\subsubsection{Halaman Hasil Perhitungan}

Halaman hasil perhitungan adalah halaman yang digunakan untuk menampilkan hasil perhitungan rumus mutu pelayanan rumah sakit. Pada halaman ini parameter yang berada dihalaman mutu pelayanan akan di masukan ke dalam rumus, dan di tampilkan di halaman ini beserta dengan mencocokan nilai standar nasional rumah sakit. Halaman dapat dilihat pada gambar 3.

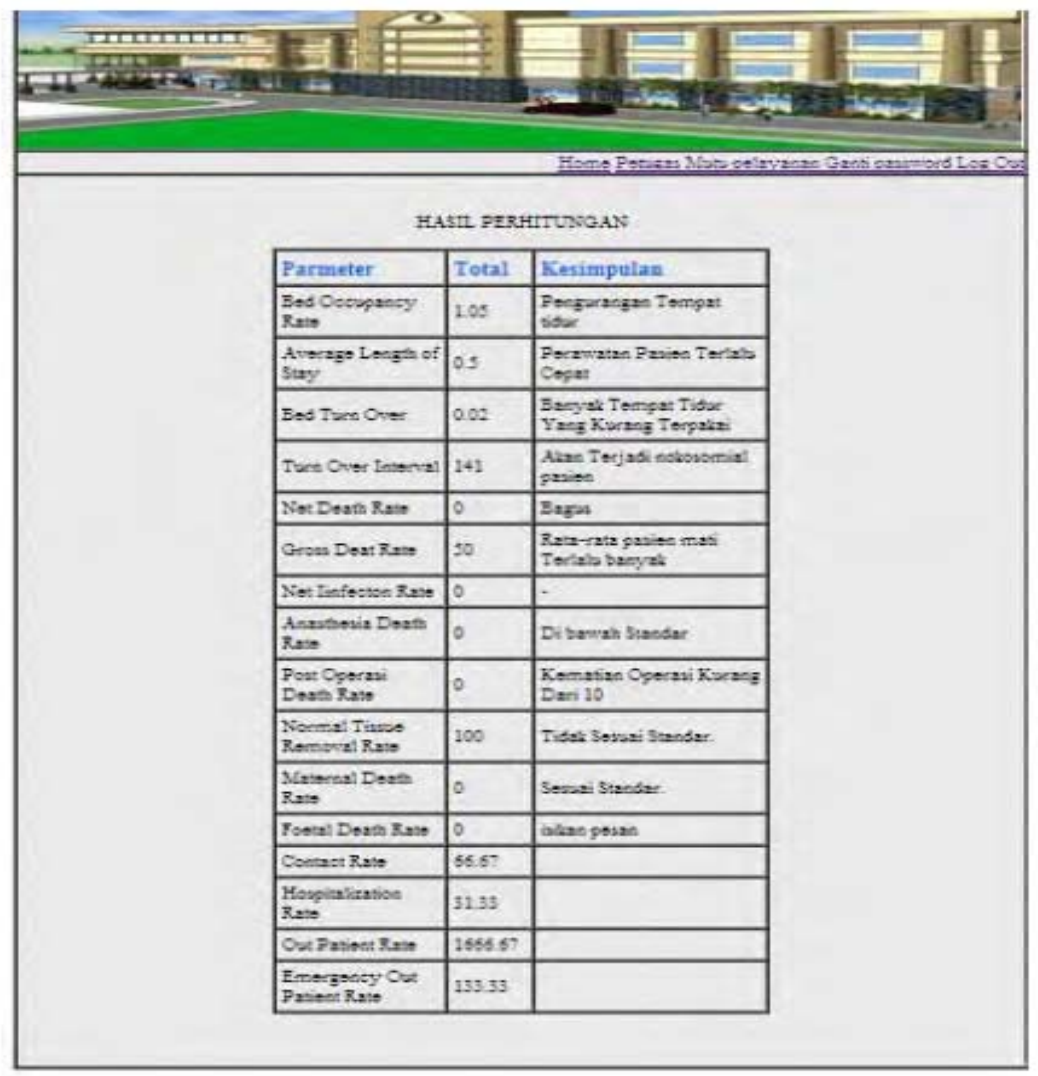

Gambar 3. Halaman Hasil Perhitungan

\subsection{Hasil Pengujian Wawancara}

Pengujian sistem dilakukan dengan wawancara uji sistem dirumah sakit, hasil pengujian berupa hasil perhitungan dan pencocokan hasil dengan nilai standar rumah sakit. Hasil tersebut apakah sesuai dengan proses yang biasa dilakukan dirumah sakit. Adapun hasil wawancaranya adalah sebagai berikut :

a. Wawancara dilakukan terhadap Pramono, Skep, Ns (narasumber) sebagai kepala ruangan rawat cepaka rumah sakit Dolopo. Dari hasil wawancara tetang system mutu pelayanan rumah sakit, saya mendapatkan banyak informasi tentang cara perhitunganya dan aturanya dalam menentukan mutu pelayanan rumah sakit.

b. Menurut narasumber system yang dibuat sudah sesuai dengan aturan di rumah sakit tersebut, tata cara pendaftaran pasien dan tindakan pasien sudah benar, namun sistem tersebut harus di kembangkan kembali agar dapat mencakup lebih banyak data pasien.

c. Dalam rumah sakit Dolopo hanya menggunakan enam perhitungan mutu pelayanan yaitu (BOR, ALOS, TOI, NDR, GDR, BTO), maka dengan adanya tambahan dalam penghitunganya semoga pelayanan rumah sakit Dolopo dapat lebih.

\section{KESIMPULAN}

Setelah melakukan proses diskusi hingga mendapatkan hasil analisis kebutuhan sistem, perancangan sistem, pembangunan sistem dan pengujian jalannya sistem dengan rumah sakit, secara garis besar system dapat bekerja sesuai dengan perancangan yang telah dirancang sebelumnya. Kesimpulan yang diperoleh dari sistem ini adalah sebagai berikut: 
a. Sistem informasi mutu pelayanan rumah sakit dapat berjalan sesuai dengan hasil analisis kebutuhan sistem dengan menerapkan rumus mutu pelayanan rumah sakit dan hasil standar nasional rumah sakit.

b. Proses perhitungan pada sistem yaitu Bed Occupancy Rate (BOR), Average Length Of Stay (ALOS), Bed turn over (BTO), Turn over interval (TOI) ,Net death rate (NDR), Gross death rate (GDR),Net infection rate, Anasthesia death rate, Post operation death rate, Normal tissue removal rate, Maternal death rate, Foetal death rate,Contact rate(5mil), Hospitalization rate, Out patient rate Emergency out rate patient sudah sesuai dengan proses yang biasa dilakukan front office dan manajemen dengan cara melakukan pengitungan dengan menggunakan Microsoft xl.

\section{DAFTAR PUSTAKA}

[1] Azwar, Azru1.1996. Pengantar Administrasi Kesehata. Binarupa Aksara; Jakarta

[2] Fitri.2013.Pengertian Mutu Dan Pentingnya Mutu Dalam Pelayanan Kesehatan (Online) http://fitriunipdu.blogspot.com/2013/03/pengertan-mutu-dan-dalam-pelayanan.html. Diakses: 25 Februari 2014.

[3] Muninjaya.A.A (2004). Manajemen kesehatan Gde Muninjaya.A.A (ed), Aplikasi manejemen Rumah sakit(220-234). Jakarta:BukuKedokteranEGC.

[4] Rahmawati, A. F. 2013. "Mutu Pelayanan Kesehatan Berdasarkan Dimensi Dabholkar di Ruang Rawat Inap Penyakit Dalam. ’Jurnal Administrasi Kesehatan Indonesia1(2): 134. 